\title{
Assessment of the Physicochemical Quality Indicators and Microbiological Effects of Brazilian Ozonized Vegetable Oils
}

\author{
Maritza F. Díaz, ${ }^{\circledR * a}$ Márcia C. C. Veloso, ${ }^{\circledR b}$ Pedro A. P. Pereira, ${ }^{\circledR c}$ Yaima Sánchez, ${ }^{\circledR d}$ \\ Iran Fernández ${ }^{e}$ and Jailson B. de Andrade ${ }^{\circledR c}$ \\ ${ }^{a}$ Faculty of Medicine, School of Chemistry and Pharmacy, Universidad Andres Bello, \\ Sazie No 2320, Santiago, Chile \\ ${ }^{b}$ Química Orgânica, Universidade Federal Fluminense, s/n Outerio de São João Batista, \\ 24020-007 Niterói-RJ, Brazil \\ 'Instituto de Química, Universidade Federal da Bahia, 40170-110 Salvador-BA, Brazil \\ ${ }^{d}$ Chemistry Department, University of Concepción, 129 Edmundo Larenas Street, \\ Bio Bio, Concepción, Chile \\ ${ }^{e}$ National Center for Scientific Research, Ozone Research Center PO Box 6414, Cubanacán, \\ Playa, Havana, Cuba
}

\begin{abstract}
The study of quality indicators in the process of obtaining ozonized vegetable oils is useful for monitoring the ozonation reaction. The Brazilian oils "dendê", soy, corn, rice and sunflower were studied, all of them were ozonated applying different doses of ozone. Ozonized oils were evaluated by determining the physicochemical indexes of peroxide, acidity, iodine and density in addition viscosity, fatty acid composition and microbiological activity were determined. The results showed that of the five ozonized oils evaluated, "dendê" oil exhibited a higher peroxide index, approximately 1746 mmol-equiv $\mathrm{kg}^{-1}$, using an applied ozone dose of $97 \mathrm{mg} \mathrm{g}^{-1}$, during an hour and a half of the ozonation reaction. This result could be explained by its chemical composition, rich in oleic acid that facilitates the reaction with ozone due to its spatial conformation. It was also demonstrated that "dendê" oil exhibits a greater antibacterial activity with minimum inhibitory concentration (MIC) values ranging from 1.9 to $4.75 \mathrm{mg} \mathrm{mL}^{-1}$ against Staphylococcus aureus, Pseudomonas aeruginosa and Escherichia coli. It is suggested that the ozonated "dendê" oil presents greater possibilities to be used in the preparation of pharmaceutical or cosmetic formulations.
\end{abstract}

Keywords: ozonized vegetable oils, "dendê" oil, physicochemical parameters, fatty acid composition, antibacterial activity

\section{Introduction}

Fats and oils are present in every single moment of our lives. We use them in our feeding, in our hygiene, in the preservation of our health, and in countless products we used and/or consume daily. ${ }^{1,2}$ To obtain a vegetable oil with the required quality it is necessary to measure a group of characteristics and attributes both sensory and physical and chemical to establish its acceptance level. ${ }^{3,4}$

Since last century, it is a known fact that when a vegetable oil reacts with ozone it is formed a group of oxygenated compounds which provide antimicrobial effects to the oil,

\footnotetext{
*e-mail: maritza.diaz@unab.cl
}

for that reason they have been used of the medicine and cosmetology fields. ${ }^{5,6}$ It should be noted that ozonated olive oil is the most widely used in Europe, while ozonated sunflower oil has been the most widely used in Cuba.,

Vegetable oils exhibit different physicochemical properties, which depend on the length of the carbon chain and the degree of unsaturation, so the search for other vegetable oils that can be studied by the ozonation reaction would provide new substrates for the study of the correlations between its physicochemical properties and its biological effects. ${ }^{9,10}$

An attractive substrate to be studied has been the "dendê" oil, manufactured and marketed in Brazil, which is obtained from the mesocarp of the fruit of the palm tree, and 
is used mainly in Bahian cuisine and for the manufacture of cosmetics. ${ }^{11,12}$ In addition, Brazilian edible quality oils obtained from seeds such as soy, corn, rice and sunflower are also studied and compared.

It is known that, in order to follow an ozonation reaction of vegetable oils, several quality indexes such as acidity, iodine, density and viscosity must be taken into account, but mainly the peroxide index as a control of the reaction. ${ }^{6}$ Due to this, it is necessary to study them to homogenize, evaluate and compare these different quality indicators in ozonated oils.

The objective of this research is to study the compounds resulting from the ozonation reaction of the Brazilian vegetable oils "dendê", soybean, corn, rice and sunflower which are evaluated by physical-chemical analysis such as peroxide, acidity, iodine, density and viscosity. Fatty acid composition will also be determined by gas chromatography and antimicrobial activity. This study aims to select the best substrate that could be used in pharmaceutical and cosmetic formulations.

\section{Experimental}

\section{Solvents and reagents}

Glacial acetic acid, chloroform, potassium iodide, sodium thiosulfate, starch, ethanol, ether, potassium hydroxide, phenolphthalein, iodine bromide, toluene, dimethoxypropane were purchase from Merck S.A. (representation in Havana, Cuba).

Edible oil of "dendê" was obtained from Tropicana Brazilian Industry (Salvador, Brazil) and soy, corn, rice and sunflower edible oils were obtained from especial oils Liza, São Paulo, Brazil.

\section{Ozonation procedure}

Five ozonation reactions were performed, one for each oil. Edible vegetable oil $(50 \mathrm{~mL})$ was placed into a bubbling reactor where ozone reaction took place in water bath, at room temperature $\left(25^{\circ} \mathrm{C}\right)$.

The ozonation was allowed to continue for $90 \mathrm{~min}$, employing medicinal oxygen as ozone source. Applied ozone dosages (AOD) 32; 65 and $97 \mathrm{mg} \mathrm{g}^{-1}$, were obtained through different bubbling times $(0.5,1$ and $1.5 \mathrm{~h})$. Applied ozone dosages were chosen to achieve peroxide values ranged between 400 and 1800 mmol-equiv $\mathrm{kg}^{-1}$. Three samples were taken in each ozonation procedure, respectively. Three replicates were carried out for each dosage. Replicates were pooled for each ozone dosage. Samples were stored at $2-8{ }^{\circ} \mathrm{C}$ for $24 \mathrm{~h}$ before analysis.

\section{Ozone generation}

Ozone was generated passing oxygen through an Ozoney model SL-4M ozone generator (Cuba), at a fixed voltage $(170 \mathrm{~V})$, and a constant flow rate of $54 \mathrm{~L} \mathrm{~h}^{-1}$. The ozone initial concentration of the resulting stream medicinal oxygen $54 \mathrm{mg} \mathrm{L}^{-1}$ was determined by Anseros Ozomat equipment (Germany).

\section{Physical chemical techniques}

\section{Peroxide index}

Peroxide index (PI) is the number expressed as milliequivalents of active oxygen in $1 \mathrm{~kg}$ of the sample. $0.5 \mathrm{~g}$ of sample was weighed and mixed with a solution of glacial acetic acid-chloroform 3:2 v/v. $0.5 \mathrm{~mL}$ of a saturated potassium iodide solution was added. The mixture was allowed to stand for two minutes, then $30 \mathrm{~mL}$ of distilled water were added and it was slowly titrated with a solution of $0.1 \mathrm{~mol} \mathrm{~L}^{-1}$ sodium thiosulfate, stirring continuously until almost yellow disappearance. $5 \mathrm{~mL}$ of a starch indicator solution were added and titration was continued until the blue color disappeared. This determination was made in triplicate for each sample of ozonized vegetable oil.

The result was calculated by the expression: ${ }^{13}$

$\mathrm{PI}=(\mathrm{M} \times \mathrm{V} / \mathrm{Pm}) \times 1000$

where, M: sodium thiosulfate concentration $\left(0.1 \mathrm{~mol} \mathrm{~L}^{-1}\right)$, $\mathrm{V}$ : volume consumed of sodium thiosulfate in the titration (mL), Pm: sample weight.

\section{Acidity index}

Acidity index (AI) is expressed in milligrams of potassium hydroxide that are required to neutralize free acids in a gram of sample. 0.9 to $1.2 \mathrm{~g}$ of sample were weighed and mixed with $50 \mathrm{~mL}$ of a mixture of equal volumes of ethanol (96\%) and ether. Subsequently, $0.5 \mathrm{~mL}$ of $1 \% \mathrm{~m} / \mathrm{v}$ solution of phenolphthalein in ethanol (96\%) was added. The mixture was titrated with a $0.1 \mathrm{M}$ solution of potassium hydroxide, until the solution became weakly pink for at least $15 \mathrm{~s}$. Three replications were made for each of the samples. The AI was calculated from the expression: ${ }^{14}$

$\mathrm{AI}=((\mathrm{V} \times \mathrm{M}) / \mathrm{m}) \times 56.1$

where, $\mathrm{V}$ is the volume of potassium hydroxide consumed in $\mathrm{mL}, \mathrm{M}$ is the molarity of the potassium hydroxide solution, $\mathrm{m}$ : is the mass in grams of the weighed sample. 


\section{lodine index}

Iodine index (II) represents the number of $\mathrm{g}$ of iodine absorbed, under the prescribed condition, by $100 \mathrm{~g}$ of the substance. 100 to $150 \mathrm{mg}$ of oil sample were weighed and mixed with $15 \mathrm{~mL}$ of chloroform and stirred until dissolved. $25 \mathrm{~mL}$ of iodine bromide solution were added and let stand for $30 \mathrm{~min}$, protected from light, stirring frequently. $10 \mathrm{~mL}$ of $10 \% \mathrm{~m} / \mathrm{v}$ potassium iodide solution and $100 \mathrm{~mL}$ of purified water were added. The iodine released was titrated with $0.1 \mathrm{M}$ sodium thiosulfate solution vigorously stirred until the yellow color almost disappeared. $5 \mathrm{~mL}$ of starch indicator solution were added. The titration continued by adding $0.1 \mathrm{M}$ sodium thiosulfate solution dropwise until the bluish color completely disappears from the sample. The same method, exactly, was carried out, but without the substance to be examined (blank). Three replications were made for each of the samples. The II was calculated from the expression: ${ }^{15}$

Iodine index $(\mathrm{II})=((\mathrm{B}-\mathrm{V}) \mathrm{M} / \mathrm{PM}) \times 12.69$

where, B: volume in milliliters of $0.1 \mathrm{M}$ sodium thiosulfate solution consumed by the blank, V: volume in milliliters of $0.1 \mathrm{M}$ sodium thiosulfate solution consumed by the sample, M: molarity of the sodium thiosulfate solution, PM: weight in grams of the sample.

\section{Density value}

Density value represents the proportion between the mass of a substance and its volume at a determined temperature $\left(\mathrm{g} \mathrm{mL}^{-1}\right) .{ }^{16}$ The density of the vegetable oil was determined with respect to water, for this, a pycnometer was used and the calculation was made by the ratio between the mass of a volume of the substance (ozonized vegetable oil) at $20^{\circ} \mathrm{C}$ and the mass of an equal volume of water at $4{ }^{\circ} \mathrm{C} .{ }^{16}$ The determinations were made in triplicate.

\section{Viscosity value}

The increase in viscosity is a measure of the condensation polymerization of the peroxides that are formed during the ozonation of vegetable oil. The determination of this parameter is carried out using a UBBELOHDE Viscometer and is based on measuring the time required for a given sample volume to pass through a properly calibrated capillary, as a measure of the internal friction force of the product. The result is expressed in units of force viscosity per unit area, (mPa s). ${ }^{17}$

\section{Gaseous chromatography (GC)}

The ozonation effects on the fatty acids composition of different oils as "dendê", soy, corn, rice and sunflower were analyzed. For gas chromatography analysis of esterified fatty acids, methyl ester derivatives were first prepared by transesterification as described by Garcés et al..$^{18}$

Gas chromatography analyzes were performed in a highresolution gas chromatography coupled to a quadrupole mass detector Shimadzu (GCMS-QP 2010), equipped with split/splitless type injector, automatic injector (AOC-20i auto-sampler). Analysis were performed in a HP-5-MS capillary column $(30 \mathrm{~m} \times 0.25 \mathrm{~mm}$ inner diameter $)$, film thickness $1 \mu \mathrm{m}$. The carrier gas for esterified fatty acids analysis was hydrogen at a flow of $1 \mathrm{~mL} \mathrm{~min}^{-1}$ and a pressure of $50 \mathrm{kPa}$. For the analysis of the fatty acids the column temperature was programmed from 100 to $170^{\circ} \mathrm{C}$ with an increase of $8^{\circ} \mathrm{C} \mathrm{min}{ }^{-1}$ and then up to $240^{\circ} \mathrm{C}$ with an increase of $2{ }^{\circ} \mathrm{C} \mathrm{min}^{-1}$, staying for $10 \mathrm{~min}$ to $240{ }^{\circ} \mathrm{C}$, (total time $51 \mathrm{~min})$. Injections were done in duplicate using an injection volume of $1 \mu \mathrm{L}$. Fatty acid methyl esters were used as external standard C14-C22 (Sigma-Aldrich Chemical Company, Brazil) to identify components.

\section{Antibacterial activity}

Antibacterial activity of each edible quality vegetable oil and each ozonized oil obtained were determined. Staphylococcus aureus ATCC 25923, Escherichia coli ATCC 25922 and Pseudomonas aeruginosa ATCC 27853 were chosen. Minimum inhibitory concentrations (MICs) and minimum bactericidal concentrations (MBCs) by agar dilution and macro dilution methods were based on Clinical Laboratory Standards of the Clinical Laboratory Standards Institute (CLSI). ${ }^{19}$ The spectrum of antibacterial activity was obtained for all samples.

\section{Statistical analysis}

Analyses were carried out in triplicate and were expressed as mean \pm standard deviation (SD). Linear regression analysis was performed using the OriginPro 8 SRO statistical analysis. ${ }^{20}$

\section{Results}

Five vegetable oils with different fatty acid composition have been ozonized, among which are "dendê", soy, corn, rice and sunflower. Table 1 shows the physicochemical parameters quality indicators of the oils studied. It can be seen that ozonized vegetable oils have different behaviors in terms of their physicochemical properties. ${ }^{6}$

Regarding the peroxide index versus the ozone dose applied to the five oils studied, there is a linear correlation with a correlation (r) and determination coefficient $\left(\mathrm{r}^{2}\right)$ 
Table 1. Physicochemical parameters of the ozonated oils studied

\begin{tabular}{|c|c|c|c|c|c|c|c|}
\hline Oil name & $\mathrm{AOD} /\left(\mathrm{mg} \mathrm{g}^{-1}\right)$ & Moles & $\mathrm{PI}^{\mathrm{a}} /\left(\mathrm{mmol}\right.$-equiv kg $\left.{ }^{-1}\right)$ & $\mathrm{AI}^{\mathrm{a}} /\left(\mathrm{mg} \mathrm{KOH} \mathrm{g}^{-1}\right)$ & $\mathrm{II}^{\mathrm{a}} /\left(\mathrm{g} \mathrm{I}_{2} 100 \mathrm{~g}^{-1}\right)$ & $\mathrm{D}^{\mathrm{a}} /\left(\mathrm{g} \mathrm{mL}^{-1}\right)$ & $\mathrm{V}^{\mathrm{a}} /(\mathrm{mPa} \mathrm{s})$ \\
\hline \multirow{4}{*}{ "Dendê" } & 0 & 0.101 & $10 \pm 0.2$ & $0.06 \pm 0.0001$ & $57 \pm 1.9$ & $0.899 \pm 0.0001$ & $40 \pm 0.02$ \\
\hline & 32 & 0.050 & $560 \pm 1.5$ & $6 \pm 0.01$ & $28 \pm 0.5$ & $0.911 \pm 0.0004$ & $98 \pm 0.03$ \\
\hline & 65 & 0.022 & $1037 \pm 2.6$ & $15 \pm 0.06$ & $12 \pm 0.1$ & $0.935 \pm 0.0025$ & $265 \pm 0.01$ \\
\hline & 97 & 0.0062 & $1746 \pm 4.3$ & $21 \pm 0.02$ & $3.4 \pm 0.05$ & $0.938 \pm 0.0002$ & $460 \pm 0.04$ \\
\hline \multirow{4}{*}{ Soy } & 0 & 0.234 & $7 \pm 0.09$ & $0.07 \pm 0.002$ & $129 \pm 0.7$ & $0.920 \pm 0.0002$ & $36 \pm 0.02$ \\
\hline & 32 & 0.195 & $450 \pm 2.2$ & $0.85 \pm 0.003$ & $103 \pm 0.3$ & $0.960 \pm 0.0003$ & $97 \pm 0.03$ \\
\hline & 65 & 0.151 & $716 \pm 3.8$ & $3.3 \pm 0.01$ & $79 \pm 0.4$ & $0.973 \pm 0.0003$ & $260 \pm 0.5$ \\
\hline & 97 & 0.113 & $1074 \pm 4.0$ & $7.5 \pm 0.08$ & $58 \pm 0.2$ & $0.987 \pm 0.0004$ & $606 \pm 1.9$ \\
\hline \multirow{4}{*}{ Corn } & 0 & 0.193 & $10 \pm 0.4$ & $0.17 \pm 0.004$ & $107 \pm 0.7$ & $0.918 \pm 0.0002$ & $48 \pm 0.02$ \\
\hline & 32 & 0.163 & $527 \pm 2.8$ & $1.2 \pm 0.09$ & $87 \pm 0.3$ & $0.950 \pm 0.0003$ & $109 \pm 0.07$ \\
\hline & 65 & 0.122 & $873 \pm 3.7$ & $3.6 \pm 0.03$ & $64 \pm 0.2$ & $0.970 \pm 0.0004$ & $249 \pm 0.4$ \\
\hline & 97 & 0.104 & $1205 \pm 4.9$ & $6.3 \pm 0.1$ & $54 \pm 0.1$ & $0.980 \pm 0.0005$ & $544 \pm 0.7$ \\
\hline \multirow{4}{*}{ Rice } & 0 & 0.188 & $10 \pm 0.1$ & $0.2 \pm 0.001$ & $104 \pm 0.4$ & $0.917 \pm 0.0003$ & $53 \pm 0.01$ \\
\hline & 32 & 0.146 & $439 \pm 2.0$ & $1.9 \pm 0.04$ & $77 \pm 0.3$ & $0.960 \pm 0.0005$ & $117 \pm 0.03$ \\
\hline & 65 & 0.115 & $731 \pm 2.8$ & $4.6 \pm 0.08$ & $60 \pm 0.4$ & $0.970 \pm 0.0006$ & $261 \pm 0.5$ \\
\hline & 97 & 0.082 & $1098 \pm 4.1$ & $10.6 \pm 0.4$ & $42 \pm 0.3$ & $0.990 \pm 0.0008$ & $591 \pm 0.8$ \\
\hline \multirow{4}{*}{ Sunflower } & 0 & 0.215 & $7.9 \pm 0.3$ & $0.2 \pm 0.001$ & $119 \pm 0.6$ & $0.919 \pm 0.0005$ & $32 \pm 0.02$ \\
\hline & 32 & 0.209 & $540 \pm 2.9$ & $2.9 \pm 0.06$ & $110 \pm 0.5$ & $0.963 \pm 0.0004$ & $99 \pm 0.02$ \\
\hline & 65 & 0.183 & $898 \pm 3.8$ & $10 \pm 0.09$ & $95 \pm 0.3$ & $0.980 \pm 0.0007$ & $298 \pm 0.4$ \\
\hline & 97 & 0.106 & $1350 \pm 5.1$ & $18 \pm 0.1$ & $54 \pm 0.1$ & $0.994 \pm 0.0003$ & $605 \pm 0.7$ \\
\hline
\end{tabular}

aValues expressed as mean \pm standard deviation. AOD: applied ozone dosage; moles: moles of double bonds; PI: peroxide index; AI: acidity index; II: iodine index; D: density value; $\mathrm{V}$ : viscosity value.

greater than 0.99 and $98 \%$, respectively, corresponding to a linear model adjustment. ${ }^{21}$ This result indicates the linear correspondence between the peroxide index and the ozone dose applied which is shown below:

Ozonized "dendê" oil (ODO) PI $=-12.431+17.54$ AOD $\left(r=0.996 \% ; r^{2}=99.26 \%\right)$

Ozonized soy oil (OSO) PI $=43.038+10.695$ AOD

$\left(\mathrm{r}=0.995 \% ; \mathrm{r}^{2}=99.01 \%\right)$

Ozonized corn oil $(\mathrm{OCO}) \mathrm{PI}=65.481+12.129$ AOD

$\left(r=0.993 \% ; r^{2}=98.7 \%\right)$

Ozonized rice oil (ORO) PI $=37.414+10.971 \mathrm{AOD}$

$\left(r=0.997 \% ; r^{2}=99.42 \%\right)$

Ozonized sunflower oil (OSFO) PI $=42.956+13.526 \mathrm{AOD}$ $\left(r=0.997 \% ; r^{2}=99.38 \%\right)$

In relation to the acidity index, an increase in this parameter was observed (Table 1) by increasing the dose of ozone applied (32, 65 and $\left.97 \mathrm{mg} \mathrm{g}^{-1}\right)$ in all the oils studied, presenting correlation $(r)$ and determination coefficients $\left(\mathrm{r}^{2}\right)$ from 0.95 and $91 \%$, respectively, as shown below:

Ozonized "dendê" oil (ODO) AI $=0.241+0.222$ AOD $\left(r=0.997 \% ; r^{2}=99.39 \%\right)$

Ozonized soy oil $(\mathrm{OSO}) \mathrm{AI}=-0.773+0.076$ AOD

$\left(r=0.955 \% ; r^{2}=91.27 \%\right)$

Ozonized corn oil $(\mathrm{OCO}) \mathrm{AI}=-29.55+0.642 \mathrm{AOD}$

$\left(r=0.983 \% ; r^{2}=96.68 \%\right)$

Ozonized rice oil $(\mathrm{ORO}) \mathrm{AI}=-0.747+0.105 \mathrm{AOD}$

$\left(r=0.960 \% ; r^{2}=92.08 \%\right)$

Ozonized sunflower oil (OSFO) AI $=-1.284+0.1868$ AOD $\left(r=0.980 \% ; r^{2}=96.06 \%\right)$

During the ozonation reaction of the five vegetable oils studied in the three ozonation times applied $(0.5 ; 1 ; 3 \mathrm{~h})$ a gradual decrease of the double bonds can be observed (Figure 1) and the iodine index (Table 1). "Dendê" oil has a lower iodine index than the rest of the oils studied, 
however, it reacts more quickly consuming $94 \%$ of the moles of double bonds, while for the oils of soy, corn, rice and sunflower decreases at 55, 50,60 and 55\%, respectively.

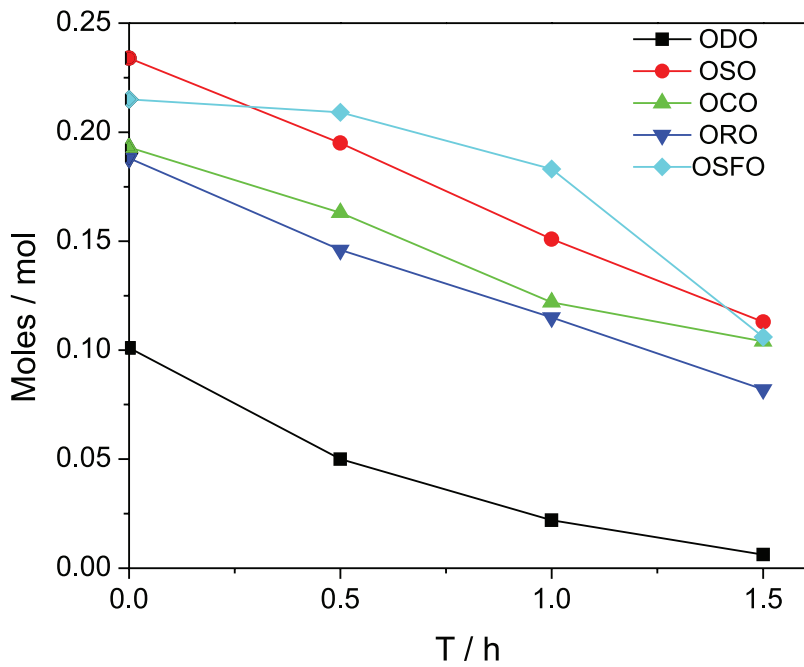

Figure 1. Behavior of the moles number (moles) against ozonated time (T). ODO: ozonated "dendê" oil; OSO: ozonated soy oil; OCO: ozonated corn oil; ORO: ozonated rice oil; OSFO: ozonated sunflower oil.

Regarding the physical-chemical density, it is shown in Table 1 that when increasing the dose of ozone applied in "dendê", soy, corn, rice and sunflower oils, they increase slightly by $4 ; 7 ; 6 ; 7$ and $8 \%$, respectively.

The viscosity $(\mathrm{V})$ is a physical parameter that increases in all the oils studied, such as "dendê", soy, corn, rice and sunflower by $91 ; 94 ; 91 ; 91$ and $95 \%$, respectively (Table 1 ). This magnitude meets an exponential correlation having a correlation and determination coefficient greater than 0.99 and $98 \%$ (Figure 2), respectively, which is shown below:

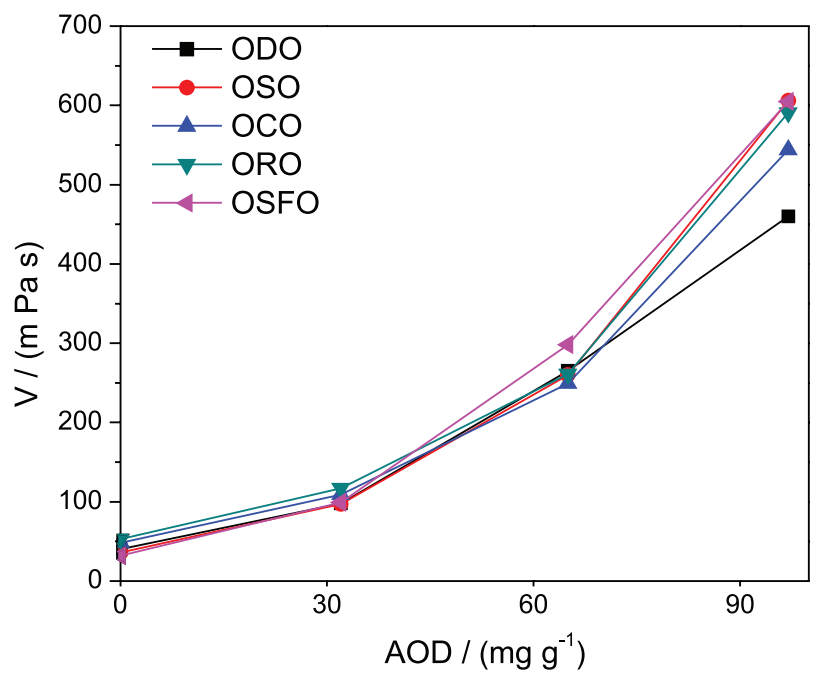

Figure 2. Behavior of the viscosity (V) against the ozone dose applied (AOD). V: viscosity; ODO: ozonated "dendê" oil; OSO: ozonated soy oil; OCO: ozonated corn oil; ORO: ozonated rice oil; OSFO: ozonated sunflower oil.
Ozonized "dendê" oil (ODO) V $=42.523 \mathrm{e}^{0.0257 \mathrm{DOA}}$

$\left(r=0.994 \% ; r^{2}=98.81 \%\right)$

Ozonized soy oil (OSO) $\mathrm{V}=37.184 \mathrm{e}^{0.0292 \mathrm{DOA}}$

$\left(\mathrm{r}=0.999 \% ; \mathrm{r}^{2}=99.88 \%\right)$

Ozonized corn oil (OCO) $\mathrm{V}=48.465 \mathrm{e}^{0.025 \mathrm{DOA}}$

$\left(r=0.999 \% ; r^{2}=99.99 \%\right)$

Ozonized rice oil $(\mathrm{ORO}) \mathrm{V}=52.81 \mathrm{e}^{0.0248 \mathrm{DOA}}$

$\left(r=0.999 \% ; r^{2}=99.99 \%\right)$

Ozonized sunflower oil (OSFO) $\mathrm{V}=35.006 \mathrm{e}^{0.0306 \mathrm{DOA}}$

$\left(\mathrm{r}=0.995 \% ; \mathrm{r}^{2}=99.01 \%\right)$

Table 2 shows the percentages of the composition of unsaturated fatty acids C18:1 (oleic acid) and C18:2 (linoleic acid) of the five oils studied obtained by the gas chromatographic analytical technique. We can see that the oil "dendê" has a high percentage composition of C18:1 monounsaturated fatty acids and the lowest percentage composition of C18:2 polyunsaturated fatty acids, while the rest of the oils such as rice, soy, corn and sunflower contain a similar or lower percentage composition of C18:1 and a higher percentage composition of $\mathrm{C} 18: 2 .{ }^{22}$ We should note that the trans isomerism determines a linear structure around the double bond, unlike the cis isomerism, where the location of the substituent atoms on the same side of the molecule produces structures of high flexibility. In its natural form, unsaturated fatty acids present mostly cis isomerism (over 95\%). All the structural functions of fatty acids are associated with cis isomerism. ${ }^{23,24}$

Table 3 shows the antibacterial activity $\left(\mathrm{mg} \mathrm{mL}^{-1}\right)$ against the microorganisms Staphylococcus aureus, Pseudomonas aeruginosa and Escherichia coli, of the five oils studied "dendê", soy, corn, rice and sunflower, for the three doses of ozone applied (32, 65 and $\left.97 \mathrm{mg} \mathrm{g}^{-1}\right)$. The minimum inhibitory concentration (MIC) and the minimum bactericidal concentration (MBC) are shown, reaching for the applied ozone dose of $97 \mathrm{mg} \mathrm{g}^{-1}$ better antibacterial activity values in all the oils studied.

\section{Discussion}

It can be seen in Table 1 that as the dose of ozone applied in all the studied oils of "dendê", soy, corn, rice and sunflower increased, higher levels of peroxides are reached. It should be noted that "dendê" oil reaches a higher peroxide index, which is 1.6 times higher than that achieved with soy oil, 1.4 times by corn oil, 1.6 times by rice oil and 1.3 times by oil sunflower. This increase in the peroxide index 
Table 2. Percentage composition of unsaturated fatty acids in the five oils

\begin{tabular}{lccccc}
\hline AOD / $\left(\mathrm{mg} \mathrm{g}^{-1}\right)$ & & 0 & 32 & 65 & 97 \\
\hline Oil name & Composition & \multicolumn{3}{c}{ Percentage composition / \% } \\
\hline \multirow{2}{*}{ "Dendê" oil } & C18:1 & $45.0 \pm 0.23$ & $31.5 \pm 0.12$ & $18.2 \pm 0.14$ & $5.8 \pm 0.08$ \\
& $\mathrm{C} 18: 2$ & $14.0 \pm 0.07$ & $12.8 \pm 0.20$ & $11.2 \pm 0.04$ & $10.5 \pm 0.05$ \\
\hline \multirow{2}{*}{ Soy oil } & $\mathrm{C} 18: 1$ & $30.07 \pm 0.27$ & $26.67 \pm 0.22$ & $22.9 \pm 0.15$ & $21.95 \pm 0.16$ \\
& $\mathrm{C} 18: 2$ & $50.51 \pm 0.09$ & $48.03 \pm 0.24$ & $36.28 \pm 0.06$ & $22.92 \pm 0.15$ \\
\hline \multirow{2}{*}{ Rice oil } & $\mathrm{C} 18: 1$ & $45.55 \pm 0.28$ & $44.10 \pm 0.28$ & $43.79 \pm 0.16$ & $42.22 \pm 0.18$ \\
& $\mathrm{C} 18: 2$ & $29.94 \pm 0.11$ & $27.01 \pm 0.23$ & $20.33 \pm 0.10$ & $17.50 \pm 0.14$ \\
\hline \multirow{2}{*}{ Corn oil } & $\mathrm{C} 18: 1$ & $37.97 \pm 0.18$ & $37.84 \pm 0.26$ & $37.02 \pm 0.12$ & $36.47 \pm 0.18$ \\
& $\mathrm{C} 18: 2$ & $44.34 \pm 0.12$ & $34.61 \pm 0.25$ & $28.91 \pm 0.13$ & $18.53 \pm 0.11$ \\
\hline \multirow{2}{*}{ Sunflower oil } & $\mathrm{C} 18: 1$ & $28.52 \pm 0.21$ & $27.12 \pm 0.12$ & $26.27 \pm 0.24$ & $24.43 \pm 0.26$ \\
& $\mathrm{C} 18: 2$ & $61.62 \pm 0.18$ & $53.82 \pm 0.14$ & $42.38 \pm 0.20$ & $25.35 \pm 0.22$ \\
\hline
\end{tabular}

AOD: ozone dose applied; C18:1 oleic acid; C18:2 linoleic acid.

Table 3. Antibacterial activity of the five ozonized oils

\begin{tabular}{|c|c|c|c|c|c|c|c|}
\hline \multicolumn{2}{|c|}{$\mathrm{AOD} /\left(\mathrm{mg} \mathrm{g}^{-1}\right)$} & \multicolumn{2}{|c|}{32} & \multicolumn{2}{|c|}{65} & \multicolumn{2}{|c|}{97} \\
\hline Oil name & $\begin{array}{l}\text { Microorganisms } \\
\text { (ATCC strains) }\end{array}$ & $\begin{array}{c}\mathrm{MIC} / \\
\left(\mathrm{mg} \mathrm{mL}^{-1}\right)\end{array}$ & $\begin{array}{c}\mathrm{MBC} / \\
\left(\mathrm{mg} \mathrm{mL}^{-1}\right)\end{array}$ & $\begin{array}{c}\mathrm{MIC} / \\
\left(\mathrm{mg} \mathrm{mL}^{-1}\right)\end{array}$ & $\begin{array}{c}\mathrm{MBC} / \\
\left(\mathrm{mg} \mathrm{mL}^{-1}\right)\end{array}$ & $\begin{array}{c}\mathrm{MIC} / \\
\left(\mathrm{mg} \mathrm{mL}^{-1}\right)\end{array}$ & $\begin{array}{c}\mathrm{MBC} / \\
\left(\mathrm{mg} \mathrm{mL}^{-1}\right)\end{array}$ \\
\hline & Staphylococcus aureus & 23.75 & 178.25 & 4.75 & 59.37 & 1.9 & 17.81 \\
\hline \multirow[t]{3}{*}{ "Dendê" } & Pseudomonas aeruginosa & 25 & 356.25 & 7.25 & 89.06 & 4.75 & 14.83 \\
\hline & Escherichia coli & 25 & 178.25 & 4.75 & 59.37 & 2.37 & 22.26 \\
\hline & Staphylococcus aureus & 22 & 44.5 & 22 & 44.5 & 9.5 & 29.6 \\
\hline \multirow[t]{3}{*}{ Soy } & Pseudomonas aeruginosa & 19 & 89 & 19 & 89 & 4.75 & 14.83 \\
\hline & Escherichia coli & 22 & 44.5 & 22 & 44.5 & 9.5 & 29.6 \\
\hline & Staphylococcus aureus & 22 & 44.5 & 22 & 44.5 & 19.5 & 30.5 \\
\hline \multirow[t]{3}{*}{ Corn } & Pseudomonas aeruginosa & 44.5 & 178 & 44.5 & 89 & 19 & 44.5 \\
\hline & Escherichia coli & 22 & 89 & 22 & 89 & 22 & 30.5 \\
\hline & Staphylococcus aureus & 22 & 44.5 & 22 & 44.5 & 14.25 & 29.6 \\
\hline \multirow[t]{3}{*}{ Rice } & Pseudomonas aeruginosa & 19 & 89 & 19 & 89 & 9.5 & 14.83 \\
\hline & Escherichia coli & 19 & 44.5 & 19 & 44.5 & 9.5 & 29.6 \\
\hline & Staphylococcus aureus & 19 & 178 & 9.5 & 22.5 & 8.5 & 19.5 \\
\hline \multirow[t]{2}{*}{ Sunflower } & Pseudomonas aeruginosa & 28.5 & 285 & 19 & 285 & 9.5 & 89.5 \\
\hline & Escherichia coli & 28.5 & 285 & 19 & 178 & 9.5 & 44.5 \\
\hline
\end{tabular}

Microorganism ATCC strains: Staphylococcus aureus ATCC 25923; Pseudomonas aeruginosa ATCC 27853 and Escherichia coli ATCC 25922; AOD: ozone dose applied; MIC: minimum inhibitory concentration; MBC: minimum bactericidal concentration.

is due to the formation of oxygenated compounds during and after the ozonation reaction, which coincides with the facts described by Díaz et al..$^{25}$ and reported by the Criegee ${ }^{26}$ mechanism for the reaction of ozone with olefins.

The good linear correlation obtained between the behavior of the peroxides index and the applied ozone dose $(0.99$ for the correlation coefficient and $98 \%$ for the determination coefficient) predicts that the peroxides index parameter is considered the main indicator of quality in the process of ozonation of vegetable oils.
The linear correlation of the acidity index and the dose of ozone applied is not as good as we expected; this could be because carboxylic acids are not a direct product of the reaction, but an indirect result of the decomposition and oxidation of the oxygenated compounds derived from the reaction. Although the relationship between the dose of ozone applied and the acidity index is not as good, we can still say that there is a linear correlation, since the coefficients of correlation is greater than 0.95 and the determination is greater than $91 \%$. 
It should be noted that the ratio of the acidity index to the ozone dose applied for "dendê" reaches a high correlation and determination coefficient of 0.997 and $99.39 \%$, respectively, which corresponds to the highest value of the index of acidity obtained for this oil $\left(21 \mathrm{mg} \mathrm{KOH} \mathrm{g}^{-1}\right)$ (Table 1).

A progressive increase in the acidity index in all the oils studied (Table 1) could be due to the decomposition of peroxidic species, the oxidation of aldehydes in carboxylic acids and also the formation of acids during the ozonation reaction. ${ }^{27}$

It is known that the reaction of ozone with unsaturated fatty acids occurs through the cleavage of double bonds..$^{28,29}$ So, it should be noted that "dendê" oil, despite having the lowest iodine value among all the oils studied, has a consumption of $94 \%$ moles of double bonds (Figure 1) reaching higher peroxide and acidity rates (Table 1).

Regarding density, it is shown in Table 1 that by increasing the dose of ozone applied in the oils of "dendê", soy, corn, rice and sunflower, the mass increases due to the formation of oxygenated compounds such as ozonides, aldehydes, hydroperoxides, etc. ${ }^{30}$

When the concentration of peroxidic compounds increases, the viscosity of the medium increases in the applied ozone dosage (AOD) range from 32 to $97 \mathrm{mg} \mathrm{g}^{-1}$ (Table 1) for all the oils studied. This increase in viscosity could be a measure of the condensation polymerization that takes place from the peroxides that are formed during the ozonation of the vegetable oils or by the formation of compounds of greater molecular weight than the triglycerides originally present in the oil..$^{31,32}$ This physical parameter quality indicator that increases between 91 and $95 \%$ presenting an exponential correlation with a correlation coefficient greater than 0.99 and determination greater than $98 \%$ in all the oils studied. ${ }^{21}$ This result corresponds to one previously developed in ozonized sunflower oil by Hernández et al. ${ }^{30}$ where the relationship between the peroxide index and the viscosity of the oil was reported as an exponential curve with an adequate coefficient of determination greater than $98 \%$.

"Dendê" oil has a higher content of monounsaturated fatty acids such as C18:1 oleic acid and small amounts of polyunsaturated fatty acid (C18:2 linoleic acid) that differentiates it from soybean, corn, rice and sunflower oils, which contain higher amount of linoleic acid C18:2 than oleic C18:1. ${ }^{22}$ We should expect that these latter oils, due to their composition rich in double bonds in carbons 9 and 12 , during the ozonation reaction have a higher oxidation that of "dendê" oil, which is rich in the double bonds of carbon 9. However, this does not happen, and we consider that it could be due to the non-linear spatial conformation showing an elbow that both acids adopt, with cis isomerism. On the other hand, due to the spatial conformation that both acids adopt, the double bond of oleic acid is more exposed to the ozonation reaction that the double bonds of linoleic acid that are more packed, ${ }^{23}$ which could be the explanation for an ozonation reaction faster in the "dendê" oil.

Regarding the study of the percentage of the composition of unsaturated fatty acids (C18:1 and C18:2) by gas chromatography of the five vegetable oils "dendê", soy, corn, rice and sunflower (Table 2), it can be observed that ozonation reaction is fast for fatty acids that are in high concentration, while the fatty acids at lower concentrations react more slowly. In this way the "dendê" oil, which has a high proportion of $\mathrm{C} 18: 1$ oleic acid will react rapidly. This could explain the selectivity of the ozone at the time of reacting with the substrates ${ }^{9}$ and the rapid ozonation of "dendê" oil where $87 \%$ of the double bonds react.

The determinations of the content of unsaturated fatty acids made to the different oils such as "dendê", soy, corn, rice and sunflower (Table 2), showed that the content of unsaturated fatty acids was decreasing and consequently increasing the peroxide index, the acidity index, the viscosity and the density. Both oleic acid and linoleic acid, which are the unsaturated fatty acids found in greater proportion in these oils,,$^{23}$ are detected in all the samples analyzed, which indicates that not all double bonds of these two acids were attacked by ozone, leaving triglycerides modified in the reaction medium by the reaction with ozone and unmodified triglycerides, which could be subsequently oxidized by the oxygenated compounds formed.

It can be observed that ozonated oils, in general, have antibacterial activity against the microorganisms studied Staphylococcus aureus, Pseudomonas aeruginosa and Escherichia coli, (Table 3). The MIC values for the applied ozone dose of $97 \mathrm{mg} \mathrm{g}^{-1}$ were for soy oil between 4.75 and $9.5 \mathrm{mg} \mathrm{mL}^{-1}$, corn oil between 19 and 22, rice oil between 9.5 and $14.25 \mathrm{mg} \mathrm{mL}^{-1}$, sunflower oil between 8.5 and 9.5 , and "dendê" oil between 1.9 and $4.75 \mathrm{mg} \mathrm{mL}^{-1}$. While, the MBC values for applied ozone dose of $97 \mathrm{mg} \mathrm{mL}^{-1}$ were for soy oil between 14.83 and $29.6 \mathrm{mg} \mathrm{mL}^{-1}$, corn oil between 30.5 and $44.5 \mathrm{mg} \mathrm{mL}^{-1}$, rice oil between 14.83 and $29.6 \mathrm{mg} \mathrm{mL}^{-1}$, sunflower oil between 19.5 and $89.5 \mathrm{mg} \mathrm{mL}^{-1}$, and "dendê" oil between 14.83 and $22.26 \mathrm{mg} \mathrm{mL}^{-1}$. It should be noted that "dendê" oil has the best antibacterial activity of all the oils studied.

These results correspond to those reported by various researchers where the biological activity of ozonized oils is attributed to oxygenated species. ${ }^{33-35}$ Currently, there are several hypotheses of the mechanism of action of ozonized oils on microorganisms, but given the nature of its main oxygenated compounds, damage occurs in the most sensitive 
biomolecules such as proteins and unsaturated lipids, due to the oxidative attack of these oxygenated compounds on the cell envelope of microorganisms. ${ }^{36-38}$ It should be noted that these ozonized oils do not pollute the atmosphere and there have been no reported cases of bacterial resistance to these substances, so the results of this study could be a contribution to their use in fighting various infections of microorganisms and the scientific development of the benefits of these oils in medicine and cosmetology.

\section{Conclusions}

The results showed that "dendê" oil has a better antimicrobial activity with an extraordinarily low MIC and $\mathrm{MBC}$ for the three microorganisms studied. In addition, with this oil a greater reaction of its moles of double bonds with ozone (94\%) is obtained, reaching a high peroxide index of 1746 mmol-equiv $\mathrm{kg}^{-1}$, thus increasing the concentration of oxygenated compounds responsible for the antibacterial effects of oil. This could be due to its chemical composition, rich in oleic acid C18:1, which has a spatial conformation of high flexibility, less packaged that facilitates its ozonation reaction.

It was possible to verify the selectivity of the ozone gas by reacting with the double bonds of unsaturated fatty acids C18:1 and C18:2 of the 5 vegetable oils studied "dendê", soy, corn, rice and sunflower through the technique of gas chromatography, showing that the ozonation reaction occurs rapidly for unsaturated fatty acid that is in greater proportion, while unsaturated fatty acid in smaller proportion reacts more slowly.

In conclusion, it is suggested that the ozonated oil "dendê" can be used in the preparation of pharmaceutical and cosmetic formulations.

\section{Acknowledgments}

The authors appreciate the financial support granted by the CITMA-CNPq project.

\section{Author Contributions}

The administration of the project and the acquisition of resources was carried out by Dr Jailson B. de Andrade and Dr Maritza F. Díaz. The conceptualization of the research was carried out by Dr Marcia Veloso, Dr Pedro Pereira and Dr Maritza F. Díaz. The validation and software were made by MSc Iran Fernández and MSc Yaima Sánchez, in addition, the writing of the article and its final editing was carried out by Dr Maritza F. Díaz. The final review of the article was carried out by all the authors.

\section{References}

1. Gunstone, F. D.; Structured and Modified Lipids; Marcel Dekker Inc.: New York, USA, 2001.

2. Durán, S. A.; Torres, J. G.; Sanhueza, J. C.; Nutr. Hosp. 2015 , $32,11$.

3. Soriano, N. U.; Migo, V. P.; Matsumura, M.; J. Am. Oil Chem. Soc. 2003, 80, 997.

4. Zanardi, I.; Travagli, V.; Gabbrielli, A.; Chiasserine, L.; Bocci, V.; Lipids 2008, 43, 877.

5. Díaz, M.; Sánchez, Y.; Gómez, M.; Hernández, F.; Veloso, M. C.; Pereira, P.; Mangrich, A. S.; Andrade, J. B.; Grasas Aceites 2012, 63, 466.

6. Menéndez, S.; González, R.; Ledea, O.; Hernández, F.; León, O. S.; Díaz, M. F.; Ozono, Aspectos Básicos y Aplicaciones Clínicas; CENIC: La Habana, Cuba, 2008.

7. Bocci, V.; A New Medical Drug, $2^{\text {nd }}$ ed.; Springer Verlag: Dordrecht, The Netherland, 2005.

8. Díaz, M.; Gavin, J.; Ledea, O.; Hernández, F.; Alaiz, M.; Garcés, R.; Ozone: Sci. Eng. 2005, 27, 247.

9. Díaz, M. F.; Hernández, R.; Martínez, G.; Vidal, G.; Gómez, M.; Fernández, H.; Garcés, R.; J. Braz. Chem. Soc. 2006, 17, 403.

10. Graciani, E.; Oils and Fats: Composition and Properties, $1^{\text {st }} \mathrm{ed}$.; Educación: Madrid, Spain, 2006.

11. Gunstone, F.; Haewood, L.; Padley, B.; The Lipid Handbook, $2^{\text {nd }}$ ed.; Chapman \& Hall: London, UK, 1994.

12. Almeid, D. T.; Nunes, I. L.; Conde, P. L.; Rosa, R. P. S.; Rogério, W. F.; Machado, E. R.; Grasas Aceites 2013, 64, 38.

13. United States Pharmacopeia and National Form, (USP-NF); Fats and Fixed Oils, 401 Peroxide Value, $30^{\text {th }}-25^{\text {th }}$ ed.; Port City Press: Baltimore, USA, 2007.

14. United States Pharmacopeia and National Form, (USP-NF); Fats and Fixed Oils, 401 Acid Value, $30^{\text {th }}-25^{\text {th }}$ ed.; Port City Press: Baltimore, USA, 2007.

15. United States Pharmacopeia and National Form, (USP-NF); Fats and Fixed Oils, 401 Iodine Value, $30^{\text {th }}-25^{\text {th }}$ ed.; Port City Press: Baltimore, USA, 2007.

16. United States Pharmacopeia and National Form, (USP-NF); Physical Tests, 699 Density, 30 ${ }^{\text {th }}-25^{\text {th }}$ ed.; Port City Press: Baltimore, USA, 2007.

17. United States Pharmacopeia and National Form, (USP-NF); Physical Tests, 911 Viscosity, 30 ${ }^{\text {th }}-25^{\text {th }}$ ed.; Port City Press: Baltimore, USA, 2007.

18. Garcés, R.; Mancha, M.; Anal Biochem. 1993, 211, 139.

19. Clinical and Laboratory Standards Institute (CLSI); Methods for Dilution Antimicrobial, Susceptibility Testing of Bacteria that Grow Aerobically M07, $11^{\text {th }}$ ed.; CLSI: Wayne, PA, USA, 2018.

20. OriginPro 8 SRO, Statistical Analysis; Origin Lab Corporation, Northampton, MA, USA, 2007. 
21. Castillo, B.; González, R.; Rev. Cubana Farm. 1996, 30, 43.

22. Firestone, D.; Physical and Chemical Characteristics of Oils, Fats and Waxes, $1^{\text {st }}$ ed.; Champaign: Illinois, USA, 1999.

23. Nakamura, M. T.; Nara, T. Y.; Annu. Rev. Nutr. 2004, 24, 345.

24. Valenzuela, A.; Morgado, N.; Rev. Chil. Nutr. 2005, 32, 88.

25. Díaz, M. F.; Gavín, J. A.; Gómez, M.; Curtilles, V.; Hernández, F.; Ozone: Sci. Eng. 2006, 28, 59.

26. Criegee, R.; Angew. Chem., Int. Ed. 1975, 14, 745.

27. Moureu, S.; Violleau, F.; Haimoud-Lekhal, D. A.; Calmon, A.; Chem. Phys. Lipids 2015, 186, 79.

28. Díaz, M.; Hernández, F.; Álvarez, I.; Vélez, H.; Ledea, O.; Molerio, J.; Rev. CENIC, Cienc. Quim. 1998, 29, 89.

29. Martínez, G.; Pérez G.; Horwat, R.; Rev. Española Ozonoterapia 2012, 2, 121.

30. Hernández, R.; Martínez, G.; Díaz, M.; Rev. CENIC, Cienc. Quim. 2004, 35, 159.

31. de Almeida, N. R.; Beatriz, A.; de Arruda, E. J.; de Lima, D. P.; de Oliveira, L. C. S.; Micheletti, A. C. In Vegetable Oil: Properties, Uses and Benefits, $1^{\text {st }}$ ed.; Holt, B., ed.; Nova Science Publishers: New York, 2016, ch. 5.
32. Díaz, M. F.; Ledea, O. E.; Regüeiferios, M. G.; Garcés, R. M.; Alaiz, M.; Martínez, F. E.; Quim. Nova 2009, 32, 2467.

33. Díaz, M.; Lezcano, I.; Molerio, J.; Hernández, F.; Ozone: Sci. Eng. 2001, 23, 35.

34. Sechi, L. A.; Lezcano, I.; Nuñez, N.; Espim, M.; Dupre, I.; Pinna, A.; Molicotti, P.; Zanetti, S.; J. Appl. Microbiol. 2001, $90,279$.

35. Curtiellas, V.; Gómez, M.; Ledea, O.; Fernández, I.; Sánchez, E.; Rev. CENIC, Cienc. Biol. 2005, 36, 1.

36. Curtiellas, V.; Ledea, O.; Rodriguez, S.; Ancheta, O.; Echevarria, M.; Sánchez, E.; Fernández, I.; Rev. CENIC, Cienc. Biol. 2008, 39, 128.

37. Komanapalli, I. R.; Mudd, J. B.; Lau, B. H.; Toxicol. Lett. 1997, 90, 61.

38. Pryor, W. A.; Uppu, R. M.; J. Biol. Chem. 1993, 68, 3120.

Submitted: November 27, 2019

Publisehed online: August 19, 2020 